\title{
Seniorers arbejdsliv på kanten - mellem at blive eller gå?
}

\section{Indledning}

I snart 30 år har seniorernes tilknytning til arbejdsmarkedet spillet en central rolle i den politiske debat. Den politiske ambition har været at få flere seniorer til at trække sig senere tilbage fra arbejdsmarkedet og er blevet omsat $i$ en serie af reformer; bl.a. i form førtidspensionsreformer (2003 og 2013) og efterløns- og pensionsreformer (1999, 2006 og 2011). En effekt af reformerne er, at det er blevet meget vanskeligt at få tilkendt førtidspension; at efterlønnen stort set er udfaset, og at pensionsalderen forventes at stige markant for at nå 72 år i 2050 (Finansministeriet, 2018).

De gennemførte reformer bygger på simple - men politisk slagkraftige - ideer om, at mennesker i deres færden styres af økonomiske incitamenter, dvs. forestillingen er, at generøse tilbagetrækningsordninger lokker eller trækker seniorerne ud af arbejdsmarkedet før tid ('pull'). Spørgsmålet er imidlertid, om idégrundlaget for reformerne og den forventede senere tilbagetrækning er virkelighedsnær? Ifølge EU's 2018-Ageing Report, der har sine tal fra Finansministeriet, forventes den gennemsnitlige tilbagetrækningsalder i 2050 ikke at være 72 år, men kun 67,5 år for mænd og 66,8 år for kvinder (European Commission, 2018). Der er med andre ord meget, der tyder på, at forestillingen om, at vi i 2050 er i stand til at arbejde, indtil vi når 72 år, bærer præg af ønsketænkning.

Det er ikke kun økonomiske incitamenter, der er styrende for tilbagetrækningsbeslut- ningen. Også normer, værdier, arbejdspladsens sociale fællesskab, ønsket om at være en del af og bidrage til det samfundsmæssige fællesskab, arbejdsevnen og arbejdsorienteringen har betydning for, hvornår vi forlader arbejdsmarkedet. I en sådan optik er generøse velfærdsordninger kun én ud af mange betingelser for menneskelig aktivitet. Tilbagetrækningsbeslutningen er med andre ord en kompleks proces, og der er især et behov for at få belyst, hvorfor nogle seniorer bliver puffet ud af arbejdsmarkedet ('push'), før de når pensionsalderen, medens andre forbliver erhvervsaktive frem til - eller ud over - pensionsalderen ('stay').

Da politikerne gennemførte de meget vidtgående reformer, har det formodentlig været på baggrund af en mistanke om, at reformerne, som påpeget i EU's 2018-Ageing Report, ikke var socialt bæredygtige. I Velfærdsforliget fra 2006 valgte man således at understrege, at indsatsen for et bedre arbejdsmiljø skulle styrkes med henblik på at forebygge nedslidning - om end disse intentioner ikke blev modsvaret af politisk handling. Ligeledes blev tilbagetrækningsreformen fra 2011 fulgt op med indførelsen af behovstestet Seniorførtidspension, der pr. 1. januar 2020 er afløst af Seniorpension, der ligeledes er behovstestet. Parallelt hermed har der været nedsat en Seniortænketank med det formål at indsamle viden om, hvad der kan få seniorerne til at blive på arbejdsmarkedet, ligesom Socialdemokratiet aktuelt er inde i overvejelser om, 
hvordan man kan konstruere en folkepensionsalder, der både er rettighedsbaseret og differentieret. De politiske aktiviteter og debatten om tilbagetrækningen fra arbejdsmarkedet er således godt i gang.

Det er denne debat, som nærværende temanummer bidrager til. Temanummerets centrale spørgsmål er: Hvad betinger tilbagetrækningstidspunktet? Hvilke faktorer får seniorer til at blive eller gå?

\section{Hvad får seniorer til at blive - eller gå?}

Når vi skal forstå seniorernes beslutninger om tilbagetrækning, så giver det mening at foretage en skelnen mellem, på den ene side, de objektive vilkår eller omverdenen (f.eks. et dårligt arbejdsmiljø eller generøse tilbagetrækningsordninger), der betinger beslutningen om at trække sig tilbage - og på den anden side, individets arbejdsevne (herunder helbredstilstand) og adfærdsdispositioner, som er med til at udløse tilbagetrækningsbeslutningen. Det er samtidigt samspillet mellem de to - vilkår og arbejdsevne - som er det springende punkt. Et dårligt helbred udløser således ikke nødvendigvis en beslutning om at trække sig tilbage. Selvom man har en nedsat arbejdsevne, kan man godt have lyst til at være deltagende på arbejdsmarkedet, og mulighederne for at forblive optimeres, hvis man tilbydes ændrede arbejdsvilkår, f.eks. i form af fleksible arbejdstider eller et mere ergonomisk jobdesign. Pointen er således, at det i et fastholdelsesperspektiv er afgørende vigtigt, at der (livslangt) etableres en balance mellem de krav, som arbejdslivet stiller til det enkelte individ, og de ressourcer, som det enkelte individ besidder (Ilmarinen, 2005).

Når vi ser på samspillet mellem de betingende og udløsende faktorer, der rammesætter tilbagetrækningstidspunktet, så peger den eksisterende forskningslitteratur på, at tilbagetrækningen er betinget af interaktio- nen mellem 3 forskellige niveauer: mikro-, meso- og makroniveau.

\section{Mikro}

Det er rimeligt veldokumenteret, at tilbagetrækningstidspunktet er betinget af individuelle faktorer så som helbred, alder, køn og uddannelse. Kvinder trækker sig før mænd, samtidig med at jo dårligere helbred og jo dårligere uddannet og jo ældre man er, desto større er sandsynligheden for, at man vil trække sig tilbage fra arbejdsmarkedet (se f.eks. Jensen, 2011). Dårlig uddannelse eller et dårligt helbred gør, at man puffes ud af arbejdsmarkedet, dvs. man er genstand for såkaldte 'Push'-mekanismer.

Imidlertid er det ikke alle med præcis samme uddannelse, alder og helbred, som trækker sig tilbage på præcist samme tidspunkt. Også arbejdsmarkedsorienteringen og den måde, hvorpå man oplever, om arbejdet er identitetsdannede, influerer på tilbagetrækningstidspunktet, ligesom ens position på arbejdsmarkedet også spiller en rolle, f.eks. om man er i beskæftigelse eller arbejdsløs. Hvis man er arbejdsløs, og forgæves søger arbejde, kan man blive ramt af den såkaldte modløshedseffekt, der kan understøtte beslutningen om at forlade arbejdsmarkedet (Wang \& Shultz, 2010). Dette angiver tillige, at ens jobhistorik har betydning for tilbagetrækningstidspunktet.

Økonomiske forhold og privatforbruget influerer også på, hvornår man forlader arbejdsmarkedet. Man glemmer ofte, at efterlønnen ikke giver adgang til et liv i sus og dus. Hvis man derfor har et stort privatforbrug eller dyre levevaner, har man simpelthen ikke råd til at forlade arbejdsmarkedet. Dette fænomen omtales ofte som, at man er fastlåst ('stuck') på arbejdsmarkedet (Jensen, 2011).

Omvendt kan en stærk orientering mod nye oplevelser gøre, at man hopper ud af arbejdsmarkedet. Man kan søge sociale ge- 
vinster, dvs. forløse ønskerne om at være mere sammen med børn eller børnebørn, eller man kan søge oplevelsesgevinster, f.eks. realisere friværdien og købe en sejlbåd og rejse jorden rundt; man kan også hellige sig golfen eller forløse kunstneriske ambitioner (male/skrive). Hvis man hopper ('Jump') ud af arbejdsmarkedet, kan man være parat til at gå dramatisk ned i indkomst mod til gengæld at kaste sig ud i aktiviteter, man har drømt om hele livet.

Som angivet peger den eksisterende forskning på, at faktorer så som uddannelse, helbred, køn, alder, arbejdsorientering mv. er vigtige prædiktorer for tilbagetrækningstidspunktet. Imidlertid påpeger Claus D. Hansen, Morten Kyed, Kirsten Fonager og Henrik Bøggild i artiklen Rigtige moend på retroete? - Bygningshåndvoerkeres sociale køn og forestillinger om tilbagetraekning, at det sociale køn, forstået som maskulinitetsforståelser, kønsidentitet og kønsidealer påvirker tilbagetrækningstidspunktet, hvilket hidtil har været helt overset $\mathrm{i}$ analyser af den forventede tilbagetrækningsadfærd. Undersøgelsesresultaterne bygger på surveys gennemført blandt mænd beskæftiget i bygge- og anlægsbranchen, hvor der udføres fysisk betonet arbejde. Der skelnes mellem bygningshåndværkere, der identificerer sig med traditionelle kønsidealer, og håndværkere med såkaldt 'moderne idealer' om at være omsorgsfuld og familieorienteret. Artiklen viser, at det sociale køn (kønsidealerne) har betydning for den forventede tilbagetrækningsalder, typen af tilbagetrækning (efterløn, førtidspension, pension), samt de forventede årsager (helbred versus jump mod sociale gevinster) til at forlade arbejdsmarkedet.

På mikroniveau har også livsforløbsperspektivet været et underbelyst emne. Vi ved allerede, at social klasse har betydning for tilbagetrækningstidspunktet. Imidlertid analyserer Jeevitha Yogachandiran Qvist i artiklen Social klasse og tidlig tilbagetroekning fra arbejds- markedet: Et livsforløbsperspektiv, betydningen af arbejdsløshed og dårligt helbred over livsforløbet for risikoen for tidlig tilbagetrækning fra arbejdsmarkedet. Artiklen bygger således på en hypotese om, at social udsathed, der opleves tidligere i livet, f.eks. arbejdsløshed og dårligt helbred, har konsekvenser senere i livet. Forfatteren finder empirisk belæg for, at der er tale om såkaldt 'kumulativ stratifikation', idet personer fra arbejderklassen, i højere grad end personer fra den højere serviceklasse, tidligere i livet eksponeres for arbejdsløshed eller dårligt helbred, hvilket forstærker forskellene i den 'push'-betingede risiko for tidlig tilbagetrækning.

\section{Meso}

Tilbagetrækningen er sjældent en funktion af individers nyttemaksimerende kalkulationer. Som hovedregel foregår beslutningen om at trække sig i en social kontekst, hvorfor især familieforholdene spiller en central rolle for tilbagetrækningstidspunktet. Ægtefæller drøfter og synkroniserer deres tilbagetrækning, og da kvinder som oftest er yngre end manden i et parforhold, vil begge ægtefæller forlade arbejdsmarkedet, når manden når pensionsalderen (Friis, 2011). Det er i dette perspektiv interessant at notere sig, at kvinder, der bor alene, trækker sig langt senere end kvinder, der har en ægtefælle (Nielsen, 2004).

På den enkelte virksomhed har arbejdets tekniske (om arbejdet er fysisk/stillesiddende), organisatoriske (om der er autonomi i arbejdet) og sociale dimensioner (om man værdsættes og får anerkendelse fra ledelse og kollegaer), samt arbejdspladsens normer for tilbagetrækning, betydning for tilbagetrækningstidspunktet. Et hårdt fysisk arbejde og et dårligt arbejdsmiljø betinger tidlig tilbagetrækning fra arbejdsmarkedet (se f.eks. Thorsen, Jensen \& Bjørner, 2016). Samme effekt kan organisatoriske og teknologiske 
forandringer have, især hvis de indebærer, at der sker en overlevering af arbejdsopgaver til yngre medarbejdere.

I artiklen Sammenhoeng mellem ny teknologi i seniorarbejdslivet og beslutningen om at forlade arbejdsmarkedet før eller efter folkepensionsalderen, diskuterer Emil Sundstrup, Jeppe Ajslev $\&$ Lars Louis Andersen, i hvilket omfang indførelsen af ny teknologi har betydning for tilbagetrækningsbeslutningen. Forfatterne sammenligner forskellige jobfunktionskategorier, dvs. arbejde med symboler (kontorarbejde, administration, analyse, IT mv.), produktion ( hvor jobfunktionen omhandler at bearbejde, producere eller flytte ting) og mennesker (service, omsorg osv.), og de finder, at indførelsen af ny teknologi har den største 'push'-effekt blandt personer, der arbejder med mennesker. Et andet centralt fund er endvidere, at måden, hvorpå ny teknologi implementeres, kan have betydning for, om seniorerne forlader arbejdsmarkedet før eller efter folkepensionsalderen. Det afgørende er, om seniorerne bliver inddraget i den måde, hvorpå teknologi indføres. Hvis dette sker, vil sandsynligheden, for at de forlader arbejdsmarkedet grundet ny teknologi, være relativ lav. Forfatterne bidrager således til den eksisterende viden gennem et særligt fokus på organisatoriske processer, som kan have betydning for seniorers beslutninger om tilbagetrækning fra arbejdsmarkedet.

I et tilbagetrækningsperspektiv er det ligeledes vigtigt, om virksomhederne gør brug af senior- eller livsfasepolitikker. Internationale studier har klart demonstreret, at arbejdsgiverorkestrerede HR- og seniorpolitikker i betydelig grad kan motivere seniorerne til at forlænge deres arbejdsliv. Seniorpolitikker handler om (1) Rekruttering og afvikling, (2) Uddannelse, udvikling og forfremmelse, (3) Fleksible arbejdsforhold, (4) Ergonomisk jobdesign og (5) Bearbejdning af holdninger over for ældre medarbejdere (se f.eks. Walker, 1998). De mest udbredte - og mest studerede
- seniorpolitikker handler om fastholdelse, og de mest anvendte seniorpolitikker på danske virksomheder er 'arbejdstidsreduktion' og 'fleksibilitetsfremmende' tiltag (Jensen, Nielsen \& de Tavernier, forthc. 2020).

Set i relation til netop dét fokus præsenterer Per H. Jensen, Henrik Lauridsen Lolle og Wouter De Tavernier ny viden, når de i artiklen Ansaettelse of seniorer: Hvilken type virksomheder rekrutterer seniorer - og hvorfor? retter blikket mod danske virksomheders ny-rekruttering af ældre medarbejdere. Forfatterne finder, at det især er strukturelle træk ved virksomhederne, der betinger rekrutteringsmønstrene. Store virksomheder, hvor der i forvejen er mange ældre ansatte, og hvor ledelseslaget har en høj alder, er i særlig grad tilbøjelige til at nyrekruttere blandt ældre segmenter i arbejdsstyrken. Dermed bidrager artiklen med en dybere forståelse af, hvordan økonomiske, sociale og organisatoriske forhold i danske virksomheder påvirker sandsynligheden for, at der rekrutteres seniorer.

\section{Makro}

På makroniveau er seniorernes tilbagetrækning betinget af den generelle konjunktursituation. Erfaringerne peger således på, at seniorarbejdskraften historisk har været anvendt som en 'buffer'. I perioder, hvor arbejdsløsheden har været høj, er seniorerne blevet puffet ud af arbejdsmarkedet, medens seniorerne i perioder med lav arbejdsløshed er blevet rekrutteret eller fastholdt $i$ arbejdsstyrken.

Denne bufferfunktion har i Danmark været understøttet af relativt generøse tilbagetrækningsordninger, først og fremmest efterlønsordningen, der har gjort, at danske seniorer - som seniorer overalt i Europa - er blevet sendt på pension (efterløn) for at "skabe plads" til deres yngre kollegaer (Blossfeld, Buchholz \& Kurz, 2011); dvs. velfærdsordningerne har gjort, at det har været nemt 
og problemfrit (det har ikke skabt social uro) at skille sig af med seniorarbejdskraften. En række studier har påpeget, at generøse tilbagetrækningsordninger så at sige lokker ('Pull') seniorerne ud af arbejdsmarkedet. Imidlertid har generøse velfærdsordninger ikke en automatisk udløsende effekt på tilbagetrækningen. Generøse ordninger kan betinge tilbagetrækningen, men velfærdssystemerne er kun en af mange betingelser for menneskelig aktivitet.

I det omfang generøse tilbagetrækningsordninger konstrueres i perioder med en betydelig arbejdsløshed, vil det alt andet lige påvirke befolkningens kulturelle orienteringsmåder. Guillemard (2003) har således påpeget, at der i mange europæiske lande i 1970'er og 1980'er opstod et såkaldt 'tidlig tilbagetrækningskultur', som dog i Danmark fra cirka 2000 langsomt - men sikkert - er rullet tilbage. Bl.a. takket være nogle meget gunstige økonomiske konjunkturer, der har skabt betingelserne for nogle meget vidtgående tilbagetræknings- og pensionsreformer.

Den første kronik i dette temanummer; Seniorarbejdslivet skal vaere både bedre og loengere, er skrevet af Harald Børsting, i rollen som formand for Seniortænketanken. Heri foretager Børsting overvejelser over, hvilke initiativer der på makroniveau må igangsættes, med henblik på at få seniorerne til at blive nogle ekstra år på arbejdsmarkedet. Det påpeges i kronikken, at arbejdsmarkedets funktionsmåde må ændres; at et diskriminerende syn på ældre skal ophøre, og at arbejdsmarkedets centrale parter bør spille en centrale rolle i forsøgene på at igangsætte sådanne forandringer, bl.a. ved at understøtte udbredelsen af fleksible løsninger. Ligeledes argumenteres der for, at arbejdsmarkedspolitikken må oprustes, og at ledige seniorer skal hjælpes hurtigt tilbage i jobs. Med afsæt i sådanne initiativer mener Børsting, at det er muligt at ændre kulturen og styrke fastholdelsesindsatsen på arbejdsmarkedet.
Temanummerets anden kronik: Seniortoenketankens forståelse af seniorernes arbejdsliv - en kritik, skal læses som en kommentar og kritisk læsning netop af Seniortænketankens seneste rapport. Kronikørerne, Niels Møller og Lisbeth Theilgaard peger på, at tænketanken hovedsageligt fokuserer på at afhjælpe negative arbejdsmiljøfaktorer med henblik på at skåne og dermed fastholde seniorerne. Baseret på metoden 'fortidsværksteder', hvor seniorer ser tilbage på deres arbejdsliv, er det imidlertid betydningen af de positive ressourcer $\mathrm{i}$ arbejdet og seniorerne som ressourcefulde, der springer i øjnene. Kronikørerne argumenterer således for, at man bør differentiere blandt gruppen af ældre og anerkende, at mange er ressourcefulde og fastholdes i arbejdet gennem et fokus på udfordringer, mening og indflydelse i arbejdet.

I tråd med dette ressourceperspektiv har Peter Plant skrevet en fyndig debatartikel, som plæderer for en vejledningsindsats rettet specifikt mod ældre arbejdstagere. Under overskriften Vejledning for aeldre: Geronotovejledning? og med henvisning til livslang læring og seniorer som 'det grå guld' på arbejdsmarkedet, peger Plant på behovet for en individuel og målrettet vejledning i overgangen fra én livsfase til en anden - uanset om det handler om en reorientering af karrieren; om frivilligt arbejde eller om at finde en ny balance mellem arbejds- og fritidsliv.

Temanummeret afsluttes med Palle Smed's anmeldelse af bogen: Arbejdet forstået bagloens - erfaringer fra 40 års arbejdsliv, som er forfattet af Mads Christoffersen, Lisbet Theilgaard \& Niels Møller, udgivet på Frydelund.

Temanummerets artikler giver os således en bred palette af bud på faktorer, som alle har betydning for, hvorvidt seniorer vælger at blive på arbejdsmarkedet eller ej. Set på tværs tegner der sig (som minimum) tre væsentlige politiske pointer: For det første, at der er mange måder at være 'senior' på. Nogle er nedslidte; nogle er fulde af ressourcer og 
har mod på at arbejde både længe og meget, mens andre er mere orienterede mod at gøre en forskel som frivillig eller i egen familie. Det peger på vigtigheden af at have et fleksibelt tilbagetrækningssystem, der kan differentiere mellem gruppen af seniorer, som ellers nemt skæres over én kam. For det andet, kan såkaldt 'seniorpolitik' ikke nødvendigvis afgrænses til de ældre. Fordi vores arbejdsmiljø og vores sundhed gennem hele livet har stor betydning for, hvordan vi bliver ældre, så er 'seniorpolitik' i virkeligheden relevant for os alle - unge

\section{RefERENCER}

Blossfeld, H. P., Buchholz, S. \& Kurz, K. (Eds.) (2011). Aging Populations, Globalization and the Labor Market: Comparing Late Working Life and Retirement in Modern Societies. Cheltenham: Edward Elgar.

European Commission (2018). The 2018 Ageing Report, Institutional Paper 065. DOI:10.2765/286359

Finansministeriet (2018). Finansministerens svar til Folketingets Finansudvalg af 2. juli 2018 på Finansudvalgets spørgsmål nr. 386 af 6. juni 2018. Tilgængelig på: https://www. ft.dk/samling/20171/almdel/fiu/spm/386/ svar/1501772/1920527.pdf

Friis, K. (2011). 'Det er så yndigt at følges ad: tilbagetrækningen fra arbejdsmarkedet set i et husstandsperspektiv'. I J. G. Andersen \& P. H. Jensen (red.), Tilbagetroekning fra arbejdsmarkedet - årsager og effekter. København: Frydenlund Academic, s. 137-157.

Guillemard, A.-M. (2003). 'France: struggling to find a way out of the early exit culture'. The Geneva Papers on Risk and Insurance, 28, 558-574.

Ilmarinen, J. (2005). Towards a Longer Worklife! Helsinki: Finnish Institute of Occupational Health. som gamle. Og endelig, for det tredje, så er det tydeligt, hvordan seniorpolitik involverer en lang række af aktører og udfoldes i mange sfærer og på mange niveauer i samfundet. Der har hidtil været meget fokus på brede reformer og politiske udspil, men det er lige så væsentligt, at man lokalt, blandt ledere, HR-folk og faglige repræsentanter sætter fokus på og forholder sig aktivt til 'senior-problematikken'. Det er (også) blandt disse lokale aktører, at fundamentet for et sundt, godt og potentielt langt arbejdsliv skabes.

Jensen, P. H. (2011). 'Aldring og arbejde - en begrebsramme'. I J. G. Andersen \& P. H. Jensen (red), Tilbagetroekning fra arbejdsmarkedet: årsager og effekter, København: Frydenlund Academic, s. 35-56.

Jensen, P. H., Nielsen, P. \& de Tavernier, W. (forthc. 2020). Hvilke typer virksomheder gør en indsats for at fastholde seniorer - og hvilke kombinationer af virkemidler anvendes? I P. H. Jensen (red), Senior-Arbejds-Liv. København: Frydenlund Academic.

Nielsen, T. M. (2004). De aeldre og arbejdsmarkedet. København: Danmarks Statistik.

Thorsen, S. V., Jensen, P. H. \& Bjørner, J. B. (2016). 'Psychosocial work environment and retirement age: a prospective study of 1876 senior employees'. International Archives of Occupational and Environmental Health, 89, 891-900.

Walker, A. (1998). Managing an Ageing Workforce - A Guide to Good Practice. Dublin: European Foundation.

Wang M \& Shultz KS (2010). Employee retirement: a review and recommendations for future investigation. Journal of Management, 36, 172-206.

God loeselyst

Per H. Jensen, Mette Mogensen \& Signe Pihl-Thingvad 


\section{Tak til vore bedømmere}

Et tidsskrift som vores er stærkt afhængig af den hjælp, vi får fra vores mange bedømmere, som vurderer og kommenterer de artikler vi modtager.

Vi skal hermed fremføre en stor tak til alle de bedømmere, der har bidraget til tidsskriftet i 2019

Agnete Meldgaard Hansen

Anders La Cour

Bjarke Refslund

Bruno Clematide

Carsten Kronborg Bak

Christin Thea Wathne

Frederik Thuesen

Hanne Barbara Rasmussen

Henning Jørgensen

Henning Sørensen

Henrik Lambrecht Lund

Iben Charlotte Aamann

Ida Juul

Inge Storgaard Bonfils

Jan Kampmann

Jens Arnholtz

Jens Lind

Karen Christensen

Kelvin Baadsgaard

Klaus Levinsen
Kristian Larsen

Lars Skov Henriksen

Maja Sasser

Malene Nørskov Bødcker

Mette Lykke Nielsen

Mikkel Barslund

Mikkel Bo Madsen

Nana Katrine Vaaben

Nina Von Hielmcrone

Ole H. Sørensen

Pernille Bottrup

Peter Danholt

Peter Koudahl

Sine Lehn-Christiansen

Steen E. Navrbjerg

Steen Scheuer

Sørens Jensen

Tanja Kirkegaard

Trine Pernille Larsen

Thomas Bredgaard

Vibeke Andersen 